\title{
Apresentação
}

\section{Multilinguismo, discurso e direitos linguísticos}

autar a $62^{\text {a }}$ edição do Cadernos de Letras da UFF no tema multilinguismo discurso e direitos Linguísticos significa discutir a situação linguística de todos os Estados nacionais, mesmo daqueles que não se consideram oficialmente multilíngues e que fomentam a ilusão de uma imanência monolíngue. O problema reside, principalmente, quando esses Estados encaram as comunidades multilíngues como um entrave, como um mal que deve ser extirpado pela imposição da língua oficial. Nesse ponto, entramos no âmbito das ameaças à cidadania e aos direitos linguísticos dos falantes. A garantia desses direitos tem impacto na educação, bem como na inserção dos sujeitos nas diferentes esferas da sociedade. Vale ressaltar que estamos considerando aqui o termo "multilinguismo" aplicado tanto à pluralidade linguística dos falantes como aos contextos em que onde as línguas são faladas.

Tendo como referencial o projeto CAPES-PRInT-UFF intitulado Mutilinguismo, direitos linguísticos e desigualdade social desenhamos a temática desta edição, com o objetivo de compartilhar com o leitor reflexões que se articulam em torno do campo dos estudos da linguagem e que se pautam na luta pelos direitos linguísticos.

A presente edição toma o multilinguismo como principal norte, esperando, assim, contribuir para as questões relacionadas com as línguas em situação minoritária e com o acesso a educação linguística como direito fundamental.

$\mathrm{Na}$ entrevista que abre esta edição, o sociolinguista Philippe Blanchet responde às questões propostas por Shirlei Baptistone a respeito 
do tema discriminação linguística, definida pelo pesquisador francês como glotofobia. Nos trabalhos de Blanchet, observamos seu engajamento como agente na luta contra este tipo de segregação social.

Para entendermos como o Brasil vem, ao longo da história, tentando apagar sua diversidade linguística e construir uma imagem de país monolíngue, sugerimos a leitura do texto de Pedrina Barros de Castro. A autora pontua nas páginas da Revista de Imigração e Colonização o eco das ações implementadas pelo Governo Vargas no período do Estado Novo (1937-1945) que disseminaram o discurso nacionalista e a defesa do monolinguismo pela promoção da língua portuguesa.

Na sequência, o artigo de Marina Souza destaca as políticas linguísticas de cooficialização e de patrimonialização de línguas minoritárias no Brasil, sobretudo em relação às línguas indígenas e às línguas de imigração. Ao analisar o papel dos diversos entes federativo, após a Constituição de 1988, a autora aponta a relativa autonomia regional na tomada de decisões.

Com foco mais voltado para a área dos direitos linguísticos, o texto de Maria Clara Castellain Mayworm traça um panorama histórico do tema na legislação internacional e no ordenamento interno, bem como o desenvolvimento do Direito Linguístico como disciplina e campo de estudo. A relevância do artigo se encontra, principalmente, em demonstrar como o fortalecimento da disciplina no Brasil pode ser uma importante ferramenta para acolher demandas apresentadas pela sociedade civil em prol de um espaço linguisticamente mais plural e democrático.

$\mathrm{O}$ artigo de Ana Balestro se pauta igualmente pelo tema dos direitos linguísticos, associado, por seu turno, aos contextos de refúgio, de migração e de acolhimento. São contextos que expõem a necessidade de se pensar a diversidade linguística pelo prisma da temática abordada pela autora e de sua relação direta com os demais direitos dos sujeitos envolvidos nas situações de refúgio.

A contribuição de Ísis Berger se volta para as políticas linguístico- 
educacionais no Brasil e a gestão do multilinguismo na educação. A autora salienta a necessidade do estabelecimento de interlocuções na gestão do multilinguismo com vistas à promoção da pluralidade das línguas no país.

Maria Gabriela Braga da Silva reforça a perspectiva educacional do multilinguismo ao apresentar o Colégio Pedro II como um importante agente na democratização do ensino de línguas estrangeiras na educação pública brasileira. A autora identifica esse estabelecimento de ensino como um lugar de resistência às políticas linguísticas monolíngues.

As pesquisadoras Laurence Arrighi e Émilie Urbain baseiam-se nos discursos sobre a língua francesa que circulam em uma comunidade francófona minoritária do Canadá para refletir sobre o uso e as normas do francês na região da Acádia da Nova Brunswick. De acordo com as linguistas canadenses, os comentários sobre a língua, sejam feitos por atores sociais comuns ou por figuras públicas, revelam questões sociais, políticas e econômicas mais amplas.

Nina Rioult discute o processo de padronização desencadeado pelo movimento de revitalização da língua francesa no estado da Luisiana, nos Estados Unidos, uma região marcada pelo multilinguismo e pelo multiculturalismo de origem francesa, africana, americana e francocanadense.

Enriquecendo a temática deste número, o artigo de Joyce Palha Colaça aborda o processo de gramatização da língua guarani no Paraguai no contexto das reduções jesuítas. A autora toma como ponto de partida o período colonial, dando destaque ao papel do ensino da religião nesse processo pela produção de gramáticas das línguas americanas.

Ebal Bolácio contribui para a discussão do multilinguismo tendo como referência o exemplo do contato entre o português e o malaio em dicionários. $\mathrm{O}$ autor investiga os vocábulos de origem portuguesa no malaio da Indonésia, listados até a década de 1980, e constata que ainda há a presença de muitas palavras nessas obras. 
Finalizando o dossiê do número 62 do Cadernos de Letras, temos uma homenagem póstuma ao sociolinguista belga Jan Blommaert (19612021), tecida por Joel Windle e Daniel N. Silva. Os dois pesquisadores relembram a importância da contribuição teórica de Blommaert para os estudos de linguagem considerando que o pesquisador desenvolveu seus trabalhos de forma transdisciplinar, nas interfaces entre os estudos da linguagem, antropologia e sociologia, contribuindo, assim, para o refinamento de conceitos como ideologia linguística, superdiversidade, indexicalidade, escala e cronotopo, entre outros.

Na seção Tradução, Macedo e Freire retomam o tema abordado no dossiê deste número apresentando a tradução do artigo Decoloniality and language in education: Transgressing language boundaries in South Africa, de Carolyn McKinney (2020). No artigo, McKinney se baseia na teorização da descolonialidade para mostrar como a língua(gem) na educação política na África do Sul continua a ser moldada por uma matriz colonial de poder, o que leva ao silenciamento das crianças africanas e sua exclusão de uma educação de qualidade.

E, finalmente na seção Varia, o leitor encontrará as contribuições de Ana Larissa Oliveira, João Pedro Marques e João Flávio de Almeida No primeiro artigo, Oliveria e Marques afirmam que o elemento fático da linguagem influencia a conectividade, enriquecendo as trocas intersubjetivas realizadas em ambiente digital, e inferem que o emprego de estratégias de polidez pode afetar a comunicação cibernética. No segundo artigo, Almeida discute as noções de errância e sedentarização com o objetivo de propor uma nova perspectiva para se olhar os saberes que o autor considera excluídos dos muros acadêmicos.

Desejamos a todos uma boa leitura sobre a rica diversidade linguística e cultural aqui reunida.

Telma Pereira (UFF)

Mônica Savedra (UFF) 


\section{Entrevista}

Multilinguismo, discurso e direitos linguísticos 